\title{
Implementation Process of Project Control Systems and Performance of Rural Roads Construction Projects in Kenya: Role of Project Team Experience Diversity
}

\author{
Josiah Obiria Obare \\ $\mathrm{PhD}$ Candidate, Project Planning and Management University of Nairobi

\section{Dorothy Ndunge Kyalo} \\ Dean, School of Continuing and Distance Education, University of Nairobi \\ Angeline Sabina Mulwa \\ Resident Lecturer, University of Nairobi, Garissa Extra Mural Centre
}

John Mbugua

Resident Lecturer, University of Nairobi, Nairobi Extra Mural Centre

doi: 10.19044/esj.2016.v12n29p408 URL:http://dx.doi.org/10.19044/esj.2016.v12n29p408

\section{Abstract}

Project managers have always endeavoured to effectively implement project controls systems during execution of projects to enhance rates of projects successes. However lack of understanding of the role of diversity of experiences among the workforce has hindered the ultimate performance of the project control systems in influencing the performance of construction projects. This paper sought to establish the extent to which project team experience diversity influence on the relationship between implementation process of project control systems and performance of rural roads construction projects in Kenya. The study adopted the pragmatism paradigm and the correlational survey research design. Descriptive statistics were analysed using frequencies, percentages, arithmetic mean and standard deviation while inferential statistics were analysed using Pearson's Product Moment correlation ( $r$ ), simple regression and stepwise regression $\left(\mathrm{R}^{2}\right)$. Ftest was used to test the hypotheses. Tests of statistical assumptions were carried out before analysis. The results indicated that with $\mathrm{r}=0.533, \mathrm{R}^{2}=$ $0.284 \mathrm{~F}(1,195)=77.208$ at $\mathrm{p}=0.000<0.05, \mathrm{H}_{0}$ was rejected and concluded that there was a significant relationship between implementation process of project control systems and performance of rural roads construction projects. However with $\mathrm{r}=0.830, \mathrm{R}^{2}=0.685, \mathrm{~F}(1,193)=430.595$, at $\mathrm{p}=0.855>0.05$, the null hypothesis was failed to be rejected and therefore concluded that the significant relationship between implementation process of project control 
systems and performance of rural roads project does not depend on the interaction between implementation process of project control systems and project team experience diversity. It was therefore recommended that project team experience diversity among the professionals should be encouraged, communicated and shared for the common purpose of achieving high performance in projects.

Keywords: Project team experience diversity, Performance, Construction projects

\section{Introduction}

Project team experience diversity has an advantage of project team members responding to challenging tasks. This will happen through interaction among the workforce within which they will find combinations of ways of accomplishing the tasks based on their diverse experiences and knowledge (Sosa 2008). The reasons that this does not happen all the time when project team members with diverse experience are working on a project, was the point of concern of this paper and upon which this study was based. Faraj and Sproull (2000) argued that a team's members that have relevant knowledge does not guarantee their success in using it. However Gavetti et al. (2005) postulated that with more diverse individual experiences, team members might map current problems to past experiences more accurately. Earlier Prahalad and Bettis (1986) had suggested that when members of a team are pressed with a challenge, they would easily use differing cognitive representations more effectively to define and solve problems in new ways based on their varied experiences. Better put by Reagans et al. (2005) who says that members who have worked together before are better able to accurately locate knowledge in a group, effectively share the knowledge they possess, and then use this knowledge to reach a desired outcome. This also enables for the right task to be assigned to the right person. Our premise was therefore consistent with most of these studies and the study by Harrison et al. (2002) who added that found increased time working together would help teams take advantage of individuals' deeply held differences.

A group of individuals who have spent time working together may perform better than a group with the same amount of task experience but less experience working together (Huckman, Staats and Upton 2009). Authors such as Siemsen et al. (2009) have also argued that Prior experience working together also creates opportunities to create team beliefs such as psychological safety and positive social acceptance, and thus when these beliefs are in place, individuals might increase the quantity and quality of 
knowledge they share, resulting in better performance. Finally, even after relevant knowledge has been transferred, it still must be used to realise better performance. Then the question that remains unanswered is the extent to which project team experience diversity influence the relationship between implementation process of project control systems and performance of construction projects.

\subsection{Statement of the problem}

Successful project teams are composed of individuals who share common goals and act in the same manner. Unique individuals within organizations who have different cultural and educational backgrounds or process information differently are often asked to work together in teams to accomplish tasks (Yeager and Nafukho, 2012). These differences often create barriers to performance and hinder team and organizational success. Lack of understanding of the diversity of experiences of the workforce would hinder the ultimate performance of the team or the organisation which eventually affects the performance of projects. There is often a misunderstanding of how underlying differences can undermine the success of teams, even though organizations understand the importance of teams (Gilley et al., 2010). Within the construction industry, it has not been established how the perceived project team experience diversities by the workers influence on performance of rural roads construction projects.

Rural roads serve the majority populace of a country hence successful completion of these projects would result to improved welfare of these communities. No doubt little attention has been paid by the researchers in this area hence there is lack of information how the project team experience diversity of the workforce influence performance of these projects. Therefore this paper sought to investigate the extent to which project team experience diversity influence the relationship between implementation process of project control systems and performance of rural roads construction projects in Kenya.

\subsection{Research Objective}

The purpose of this paper was to establish the extent to which project team experience diversity influence the relationship between implementation process of project control systems and performance of rural roads construction projects in Kenya.

\subsection{Hypothesis}

The following hypothesis was tested in this study:

$\mathrm{H}_{0}$ : The strength of the relationship between implementation process of project control systems and performance of rural roads 
construction projects in Kenya does not depend on the project team experience diversity.

$\mathrm{H}_{1}$ : The strength of the relationship between implementation process of project control systems and performance of rural roads construction projects in Kenya depends on the project team experience diversity.

\section{Literature review}

Road contractors hold experience of the workers seriously. It is therefore believed that road contractors rely so much on their long term employees to deliver projects. Experience is an important source for the development of construction project managers where managers would develop new knowledge and skills through doing things (Dulaimi, 2005).

Those who have learnt through experience usually after a long time are motivated by their experience. This is explained by the expectancy theory of motivation that individuals are motivated by future expectations based on previous experience of performing a particular task in certain way and the outcome of such performance (Porter et al 1975). The anticipation of obtaining experience encourages practitioners to either develop or acquire new knowledge and skills. The challenges begin where those experiences are diversified within the team members to an extent that they bring about conflicts of interests. When such interests and conflicts prevail in the implementation process of project control systems, it would result into time, cost and quality overruns. The extreme results out of the above conflicts are costly disputes that often cause projects delay and minimize the realization of project successes.

Experience is coupled with the period one has worked in the company or the period one has worked with his/her trade. Generally it is referred to as tenure in other studies. Tenure points out to a positive influence on performance through enhancing performance. However one should be aware of the job burnout which results to poor job performance (Maslach et al, 2001). Individuals on a team who have worked together previously may help their team cope with changing tasks, which often render existing codified procedures less useful (Huckman, Staats, and Upton (2009).

Huckman, Staats, and Upton (2009) further argued that within teams, shared work experience plays into successful team performance. They further argue that familiarity within team's experiences potentially affects performance positively. On a research study based on employees in a store of a large US retail company, it was established that job immobility is known to be a function of poor performance (McKay et al., 2008). On the other hand, it was also established that performance increased with the age of employees, which, according to McKay et al., (2008) could be explained by cohort 
differences in work ethics, perhaps related to increased motivation and subsequent performance among older workers. It was also established that other factors which also influence high performance such as working full time and the positive diversity climate in a store. In concluding their study, McKay et al., (2008) reasoned that one must take into account that factors such as diversity climate perceptions and consequently variables such as race that mediate the relationships between job tenure and organisational commitment on one hand and employee retention and turnover on the other, which ultimately influence performance. This approach was also applied in the current study though in different sector to establish how tenure or period employed as an indicator of experience influences the relationship between implementation process of project control systems and performance of rural roads construction projects in Kenya.

In construction projects, most project practitioners are also interested on project managers with experience in both leadership skills and technical skills. However in several instances leadership skills are preferred. This is so because leadership skills are important in leading the workforce. This is supported by Dulaimi (2005) who did a research on the influence of academic education and formal training on the project manager's behaviour and found out that with an increased emphasize on project management systems, most construction firms are seeking professionals with better management skills rather than technical skills. Current construction project managers are focused on meeting the project targets in terms of budget, quality and time, but not the means on how to achieve these results. Toor and Ofori (2008) supports this argument by saying that managers are presumed to be production oriented since they manage project teams in day to day work while project leaders are presumed to be relationship oriented and they lead people to achieve long term objectives. In this case leaders are meant to motivate, inspire set high standards of performance, and set values grounded on dedication and devotion in influencing the project team to achieve high performance by creating those stimulating conditions in the implementation process of project control systems. Leaders validate, confirm, encourage, support, and believe in people's potential and ensure to let people realize their best potential for the betterment of the organization (Rock, 2006).

Based on these arguments and on the dismal extant information on how project team experience diversity influence the relationship between implementation process of project control systems and performance of rural roads, it was therefore necessary to establish the extent and direction of the relationship, hence this current study. 


\section{Methodology}

The study adopted mixed mode of study whereby both quantitative and qualitative approaches were used to collect and analyse data. It started with literature review. A through search for empirical literature on experience diversity, project teams and performance of projects was carried out with a sole aim of addressing the objectives of the study. Empirical studies that were found relevant and focused on experience diversity and performance of projects were included in the review. Objectives were stated and hypothesis formulated and the research instruments constructed, tested for validity and reliability. All these were guided by the pragmatism paradigm and correlational survey research design.

Quantitative data was collected from 209 respondents which represented 58\% response rate from workers in construction sites of Kenya Rural Roads Authority sponsored projects. Qualitative data was also collected from the key informants (site engineers) using in-depth interviews and focused group discussions. At all times the researcher adhered to ethical issues including; informed consent, honesty and trust, privacy, anonymity, disclosure, cultural sensitivity, harm and risk policy and voluntary participation. During data analysis and reporting, the researcher endeavoured to practice acceptable analytical methods and reporting.

\section{Results}

Data collected was analysed both descriptively and inferentially. Measures of central tendency; mean, standard deviation, percentages and frequency distributions was used to analyse non parametric data such as understanding the respondents' characteristics, while inferential statistics was used to test the hypotheses which would further be used to generalize the findings from the sample studied to population.

\subsection{Demographic profiles of respondents}

The demographic profiles in terms of gender, age group and period worked in the construction industry were collected and the results were as tabulated in Table 1.

Table 1. Demographic profile of the respondents

\begin{tabular}{lcccc}
\hline Demographic profile & Frequency & $\begin{array}{c}\text { Percentage } \\
\text { \% }\end{array}$ & $\begin{array}{c}\text { Cumulat } \\
\text { Percenta } \\
\text { \% }\end{array}$ \\
\hline Gender & & & & \\
& Male & 188 & 95.4 & 95.4 \\
& Female & 9 & 4.6 & 100.0 \\
& Total & 197 & 100 & \\
Age Group & & 25 & 12.7 & 12.7
\end{tabular}




$\begin{array}{cccc}26-30 & 41 & 20.8 & 33.5 \\ 31-35 & 37 & 18.8 & 52.3 \\ 36-40 & 26 & 13.2 & 65.5 \\ 41-45 & 18 & 9.1 & 74.6 \\ 46-50 & 10 & 5.1 & 79.7 \\ 51-55 & 18 & 9.1 & 88.8 \\ \text { Over 55 } & 22 & 11.2 & 100.0 \\ \text { Total } & 197 & 100 & \end{array}$

\section{Period worked in construction}

\section{industry}

Less than 1 year

$1-5$ years

6-10 years

11-15 years

16-20 years

Over 20 years

Total
14.7

14.7

25.9

40.6

24.9

65.5

12.2

77.7

5.6

83.3

16.7

100.0

Results from the table reveal that $95.4 \%$ of the respondents were male while $4.6 \%$ were female. Results reveals that male gender dominates the industry. The distribution of respondents of age group between 18-25 years was $12.7 \%$, and those between $26-30$ years were $20.8 \%$, while those between $41-45$ years were $9.1 \%$. The results also indicates that all age groups are well distributed in the construction industry hence distribution of experiences among the workforce. Further the results revealed that those who had worked for less than 1 year were $14.7 \%$ and those worked between 1-5 years were $25.9 \%$, and those above 20 years were $16.7 \%$. The result implied that the majority of the respondents $(85.3 \%)$ had worked in the construction industry for more than 1 year hence acquired enough experience to perform their tasks.

\subsection{Descriptive Analysis on Project Team Experience Diversity}

The respondents were asked to indicate the extent to which they considered themselves different based on the experience factors in their place of work. Project team experience diversity was measured using ten item statements constructed on a 5 point Likert scale ranging from $1=$ strongly agree to $5=$ strongly disagree. The results were as tabulated in Table 2.

Table 2: Means and Standard Deviation for Measures of Project Team Experience Diversity

\begin{tabular}{ccccccc}
\hline NO & Item & N & Min & Max & Mean & $\begin{array}{c}\text { Std } \\
\text { Deviation }\end{array}$ \\
\hline E1 & $\begin{array}{l}\text { In my department, the way I do } \\
\text { things is different from other team } \\
\text { members in this project }\end{array}$ & 197 & 1.00 & 5.00 & 2.39 & 1.710 \\
E2 & $\begin{array}{l}\text { In my department, my work } \\
\text { my } 197\end{array}$ & 1.00 & 5.00 & 1.62 & 1.294
\end{tabular}


experience is different from other project team members

E3 Having worked in different departments gives someone an experience to perform his/her job better

E4 In terms of the period I have worked, I do my work differently from others in my department

$\begin{array}{llll}197 & 1.00 & 5.00 & 1.22\end{array}$

.885

$\begin{array}{lllll}197 & 1.00 & 5.00 & 2.26 & 1.684\end{array}$

E5 In my team, other members are keen to learn from people who have different work experiences

$\begin{array}{lllll}197 & 1.00 & 5.00 & 1.09 & .454\end{array}$

E6 If someone in our team has some special experience about how to perform the team task, he or she is not likely to tell other members about $\begin{array}{lllll}197 & 1.00 & 5.00 & 2.89 & 1.771\end{array}$ it

E7 The experience I have gained from previous tasks helps me to perform well in my current task

E8 In my place of work we learn a lot from each other

E9 All the experience I have, I got it from this company

$\begin{array}{lllll}197 & 1.00 & 5.00 & 1.12 & .585\end{array}$

$\begin{array}{lllll}197 & 1.00 & 5.00 & 1.10 & .495\end{array}$

$197 \quad 1.00 \quad 5.00 \quad 4.10 \quad 1.544$

E10 I am still working in this company $\begin{array}{lllllllll}\text { because I want to gain more } & 197 & 1.00 & 5.00 & 2.08 & 1.508\end{array}$ experience.

Composite mean $=1.987$

Composite standard deviation $=1.193$ Cronbach alpha coefficient $=0.78$

Results from Table 2 indicate that majority of the respondents agreed that in their department, the way they did things was different from other team members in the project, and that their work experience was different from other project team members. The majority of the respondents also agreed that having worked in different departments, it gave them an experience to perform their job better and further the majority of the respondents agreed that in terms of the period they had worked, they perceived themselves doing their work differently from others in the same department.

Item E5 was confirmed by the majority of the respondents that in their project team, other members were keen to learn from people who had different work experiences. The majority of the respondents further agreed that if someone in their team had some special experience about how to perform a certain special team task, he or she was not likely to tell other members about it. In addition the majority of the respondents agreed that the experience they had gained from previous tasks helped them to perform well 
in their current task. However, majority of the respondents agreed that in their place of work they learnt a lot from each other.

Item E9 sought to establish whether all the experience they had, they got it from the current company. The mean score was 4.10 while the standard deviation was 1.544. This result indicates that the majority of the respondents disagreed that all the experience they had, they got it from the current company. Item E10 sought to establish whether they were working in the current company because they wanted to gain more experience. The mean score was 2.08 while the standard deviation was 1.508 . This result indicates that the majority of the respondents agreed that they still wanted to gain more experience.

The composite mean was 1.987 while the composite standard deviation was 1.193. The Cronbach Alpha coefficient of the 10 item statements was 0.652 indicating existence of moderate internal consistencies of the items that were used for measuring this variable.

These results imply that majority of the respondents perceived others as similar to them in their places of work in terms of their experience diversities based on previous employments, period employed and departments worked. Experience similarity among the respondents minimized conflict and promoted coexistence in their work places. Results obtained from interviews and focus group discussions confirmed that most of the workers in the construction companies have obtained so much experience that they sometimes challenge the qualified professionals. For this reason and for lack of credentials to show the qualifications, they preferred staying put in the same organisation. This promotes spirit de corps for the company and promotes sustained performance in their projects.

\subsection{Inferential Analysis}

Inferential analysis was carried out to establish the extent to which project team experience diversity influence the relationship between implementation process of project control systems and performance of rural roads construction projects in Kenya. Performance of the rural roads construction projects was measured in terms of completion within time, completion within quality, completion within schedule, client satisfaction, customer satisfaction and workers satisfaction. Implementation process of project control systems was measured in terms of the planning, installation and execution of processes, while project team experience diversity was measured in terms of period worked, departments worked and previous employment.

In regression, this study adopted the conceptual and statistical models for simple moderation as proposed by Baron and Kenny (1986) who defined a moderator as a qualitative (e.g., sex, race, class) or quantitative 
(e.g., level of reward) variable that affects the direction and/or strength of the relation between an independent or predictor variable and a dependent or criterion variable. Three stage stepwise regression analysis was carried out. First the predictor variable was regressed with the criterion variable. Second stage involved regressing the moderating variable with the criterion variable and the final stage involves regressing the interaction between predictor and moderating variable on the criterion variable.

\section{Step one: Inferential Analysis on Implementation Process of Project Controls Systems (PCS) and Performance of Rural Roads Construction Projects}

The regression results between implementation process of project controls systems and performance of rural projects was established. Data was collected from the respondents who were asked to rate the extent to which the 10 itemized statements on implementation process of project control systems in their organisation on a scale of $1=$ strongly agree to a scale of $5=$ strongly disagree on a Likert type scale. This was regressed with data that was collected from the respondents by asking them to rate 13 itemized statements on performance of rural roads construction projects on a Likert scale where $1=$ strongly agree to a scale of $5=$ strongly disagree. Therefore a simple linear correlation model was used to test the formulated hypothesis:

\section{Hypothesis 1}

$\mathrm{H}_{0}$ : There is no significant relationship between implementation process of project control systems and performance of rural roads construction projects in Kenya.

$\mathrm{H}_{1}$ : There is a significant relationship between implementation process of project control systems and performance of rural roads construction projects in Kenya.

\section{Correlation Model}

The mathematical model used for testing this hypothesis was as follows:

$$
\mathrm{Y}=\beta_{0}+\beta_{1} \mathrm{X}_{1}+\varepsilon
$$

Where

$\begin{array}{llll}\mathrm{X}_{1} & = & \text { Implementation Process of project control } \\ \text { systems } & & & \\ \beta_{0} & = & \text { Constant term } & \\ \beta_{1} & = & \text { Beta coefficients } & \\ \varepsilon & = & \text { Error term }\end{array}$


The results of the analysis when implementation process of project control systems variable was regressed on performance of rural roads construction projects variable were presented in Table 3.

Table 3: Correlation Results for the Influence of Implementation Process of Project Control Systems (PCS) on Performance of Rural Roads Construction Projects

\begin{tabular}{|c|c|c|c|c|c|c|}
\hline & \multirow[b]{2}{*}{ Model } & \multicolumn{2}{|c|}{$\begin{array}{c}\text { Unstandardized } \\
\text { coefficients } \\
\text { Std }\end{array}$} & \multirow{2}{*}{$\begin{array}{c}\text { Standardized } \\
\text { coefficients } \\
\text { Beta } \\
\end{array}$} & \multirow[b]{2}{*}{$\mathbf{t}$} & \multirow[b]{2}{*}{ Sig. } \\
\hline & & B & Error & & & \\
\hline \multirow[t]{2}{*}{1} & (Constant) & 1.048 & .118 & & 8.847 & .000 \\
\hline & $\begin{array}{l}\text { Implementation } \\
\text { process of PCS }\end{array}$ & .361 & .041 & .533 & 8.787 & .000 \\
\hline
\end{tabular}

Predictors: (constant), Implementation process of project control systems

Dependent Variable: Performance of Rural Roads Construction Projects

$\mathrm{F}(1,195)=77.208$ at level of significance $\mathrm{p}=0.000<0.05, \mathrm{r}=0.533, \mathrm{R}^{2}=0.284$

Correlation results in Table 3 indicates that when implementation process of project control systems and performance of rural roads construction projects are applied in the model, $\mathrm{R}^{2}=0.284, \mathrm{p}<0.05$. This therefore means that implementation process of PCS is associated with $28.4 \%$ of the variability in performance of rural roads construction projects. The resultant regression model was:

$$
\mathrm{Y}=1.048+0.533 \mathrm{X}_{1}
$$

Basing on the Beta value which in this model was $0.533, \mathrm{t}=8.787$, $\mathrm{p}<0.05$ indicated that for every unit increase in implementation process of PCS it resulted into $53.3 \%$ increase in performance of rural roads construction projects. In general the model was significant at $F=77.208$ and $\mathrm{p}<0.05$.

With $\mathrm{R}^{2}=0.284$, the results implies that $28.4 \%$ of the results would be explained by the model. The other variations of $71.6 \%$ were due to other variables not in this model or due to the error term. The null hypothesis was therefore rejected and it was concluded that there was a significant relationship between implementation process of project control systems and performance of rural roads construction projects in Kenya, however a weak relationship. Further analysis was therefore carried out to establish the influence of the project team experience diversity on the relationship.

Step two: Implementation Process of PCS, Project Team Experience Diversity and Performance of Rural Roads construction projects.

In this step the moderating variable project team experience diversity was introduced into the regression equation. The following hypothesis was tested using the model below: 


\section{Hypothesis}

$\mathrm{H}_{0}$ : The significant relationship between implementation process of project control systems and performance of rural roads project does not depends on project team experience diversity.

$\mathrm{H}_{1}$ : The significant relationship between implementation process of project control systems and performance of rural roads project depends on project team experience diversity.

The following analysis model was used:

$$
\mathrm{Y}=\beta_{0}+\beta_{1} \mathrm{X}_{1}+\beta_{4} \mathrm{X}_{4}+\varepsilon
$$

Where

$$
\begin{array}{lll}
X_{1} & = & \text { Implementation process of PCSs } \\
X_{4} & = & \text { Project team experience diversity } \\
\beta_{0} & = & \text { Constant term } \\
\beta_{1,} \beta_{4}, \beta_{14} & = & \text { Beta coefficients } \\
\varepsilon & = & \text { Error term }
\end{array}
$$

The regression results for the influence of project team experience diversity on the relationship between implementation process of project control

\begin{tabular}{|c|c|c|c|c|c|c|c|c|c|}
\hline \multicolumn{10}{|c|}{ Model Summary } \\
\hline \multirow[b]{2}{*}{ Model } & \multirow[b]{2}{*}{$\mathrm{R}$} & \multirow[b]{2}{*}{ R Square } & \multirow[b]{2}{*}{$\begin{array}{l}\text { Adjusted } \\
\text { R Square }\end{array}$} & \multirow[b]{2}{*}{$\begin{array}{l}\text { Std. Error } \mathrm{c} \\
\text { the Estimat }\end{array}$} & \multicolumn{5}{|c|}{ Change Statistics } \\
\hline & & & & & $\begin{array}{l}\text { R Square } \\
\text { Change }\end{array}$ & F Change & df & df2 & $\begin{array}{r}\text { Sig. F } \\
\text { Change }\end{array}$ \\
\hline 2 & 828 & .686 & .683 & .22695 & .403 & 248.901 & 1 & 194 & .000 \\
\hline \multicolumn{10}{|c|}{ ANOVA } \\
\hline \multicolumn{2}{|l|}{ Model } & \multicolumn{2}{|c|}{ Sum of Squares } & \multicolumn{2}{|c|}{ df } & \multicolumn{2}{|c|}{ Mean Square } & $\frac{F}{649.110}$ & Sig. \\
\hline 2 & $\begin{array}{l}\text { Regression } \\
\text { Residual }\end{array}$ & \multicolumn{2}{|c|}{$\begin{array}{c}27.706 \\
4.140 \\
31.846\end{array}$} & & & \multicolumn{2}{|l|}{$\begin{array}{c}13.853 \\
.021\end{array}$} & 649.110 & $.000^{\mathrm{c}}$ \\
\hline \multicolumn{10}{|c|}{ Coefficients } \\
\hline \multirow{2}{*}{ Model } & & & & \multicolumn{2}{|c|}{$\begin{array}{c}\text { Unstandardized } \\
\text { Coefficients }\end{array}$} & \multirow{2}{*}{\multicolumn{2}{|c|}{$\begin{array}{c}\text { Standardized } \\
\text { Coefficients }\end{array}$}} & \multirow[b]{2}{*}{$\mathrm{t}$} & \multirow[b]{2}{*}{ Sig. } \\
\hline & & & & $\mathrm{B}$ & Std. Error & & & & \\
\hline \multirow[t]{3}{*}{2} & \multicolumn{3}{|l|}{ (Constant) } & -.438 & .071 & \multirow{3}{*}{$\begin{array}{l}.861 \\
.139\end{array}$} & & -6.144 & \multirow{3}{*}{$\begin{array}{l}.000 \\
.000 \\
.000\end{array}$} \\
\hline & \multirow{2}{*}{\multicolumn{3}{|c|}{$\begin{array}{l}\text { Project Team Experience Diversity } \\
\text { Implementation of PCS }\end{array}$}} & .851 & .029 & & & \multirow{2}{*}{$\begin{array}{r}29.580 \\
4.767\end{array}$} & \\
\hline & & & & .094 & .020 & & & & \\
\hline
\end{tabular}
systems and performance of rural roads construction projects in Kenya were presented in Table 4.

Table 4: Regression Results for Implementation Process of PCS, Project Team Experience Diversity and Performance of Rural Roads construction projects.

Results from Table 4 indicates that the moderating variable project team experience diversity that was introduced into the model significantly improves the relationship between implementation process of PCS and 
performance of rural roads construction projects $\left(\mathrm{R}^{2}=0.686, \mathrm{p}<0.05\right)$. Project team experience diversity and implementation process of PCS factors are associated with $68.6 \%$ of the variation in the performance of rural roads construction projects. The values of $(F=1147.667, \mathrm{p}<0.05$ and $\mathrm{F}=649.110$, $\mathrm{p}<0.05)$ indicates that the influence of the independent variable implementation process of PCS and moderating variable project team experience diversity were significant in the model. The resultant regression model for step two is as shown below:

$$
\mathrm{Y}=-0.438+0.139 \mathrm{X}_{1}+0.861 \mathrm{X}_{4}
$$

Based on the Beta values, $\beta_{1}=0.139, \beta_{3}=0.861, \mathrm{t}=29.580, \mathrm{p}<0.05$, it indicated that a unit \% increase in implementation process of project control systems and project team experience diversity would result into 13.9 $\%$ and $86.1 \%$ increase respectively in performance of rural roads construction projects. The null hypothesis was therefore rejected and concluded that the significant relationship between implementation process of project control systems and performance of rural roads project depends on project team experience diversity.

The results implies that both implementation process of project control systems and project team experience diversity would significantly influence on performance of rural roads construction projects in Kenya.

Step three: Implementation process of project control systems, interaction term and performance of rural roads construction projects

The third and final step, the interaction term was included into the model. The following hypothesis and model was tested:

\section{Hypothesis}

$\mathrm{H}_{0}$ : The significant relationship between implementation process of project control systems and performance of rural roads project does not depend on the interaction term between implementation process of project control systems and project team experience diversity.

$\mathrm{H}_{1}$ : The significant relationship between implementation process of project control systems and performance of rural roads project depends on the interaction term between implementation process of project control systems and project team experience diversity.

The regression model used was as follows:

\begin{tabular}{lll}
\multicolumn{2}{c}{$Y=\beta_{0}+\beta_{1} X_{1}+\beta_{4} X_{4}+\beta_{14} X_{1} X_{4}+\varepsilon$} \\
Where & $=$ & Implementation process of PCSs \\
$X_{1}$ & $=$ & Project team experience diversity \\
$X_{0}$ & $=$ & Constant term \\
$\beta_{1}, \beta_{4}, \beta_{14}$ & $=$ & Beta coefficients
\end{tabular}




$$
\varepsilon \quad=\quad \text { Error term }
$$

The regression results for the implementation process of project control systems, interaction term and performance of rural roads construction projects were presented in Table 5.

Table 5: Implementation process of project control systems, interaction term and performance of rural roads construction projects

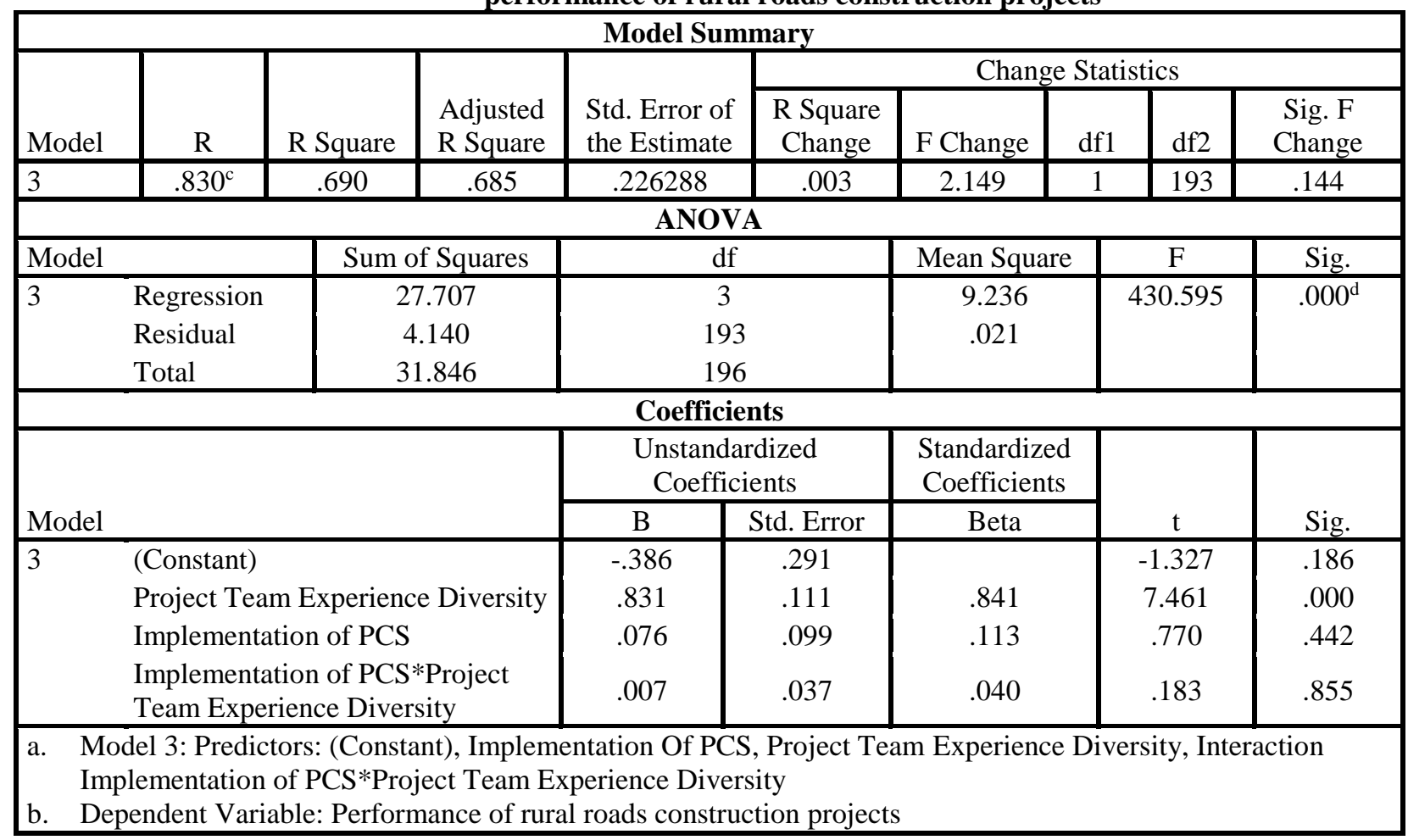

Table 5 shows the results that after introducing the interaction term in the model, and checking the statistics change they reveals that the $\mathrm{R}^{2}$ change was 0.003 that is from 0.686 to 0.690 at $\mathrm{p}<0.855$. This means that the hypothesis was tested at $14.5 \%$ confidence interval given that the $\mathrm{p}$ value was 0.855 . This confidence level was much lower than the required minimum threshold of $95 \%$ in determination of the existence of a correlation model.

The results therefore implies that a correlation model does not exist between implementation process of project control systems and the interaction term (implementation process of project control systems and the project team experience diversity, $\mathrm{X}_{1} \mathrm{X}_{4}$ ). The null hypothesis was therefore failed to be rejected and concluded that the significant relationship between implementation process of project control systems and performance of rural roads project does not depend on the interaction between implementation process of project control systems and project team experience diversity. 


\section{Discussion}

The objective of this study was to establish the moderating role of project team experience diversity on the relationship between implementation process of project control systems and performance of rural roads project. To address this objective a null hypotheses were developed and tested.

In stage one, the null hypothesis was rejected and it was concluded that there was a significant relationship between implementation process of project control systems and performance of rural roads construction projects in Kenya, however a weak relationship at $28.4 \%$. Further analysis was carried out which led to a conclusion that the relationship between implementation process of project control systems and performance of rural roads project significantly depends on project team experience diversity. In stage three, on introducing the interaction term into the equation, the null hypothesis was failed to be rejected. These study findings concurred with expectancy theory of motivation as postulated by Porter et al (1975) which states that individuals are motivated by future expectations based on previous experience of performing a particular task in certain way and the outcome of such performance. Most of the workers have worked in the road construction industry and have been rewarded by promotion and pay increment due to their variety of experiences. Some of the experienced workers could contest education and argue that; 'even without having a formal education no engineer professional can challenge me in my work'. This could be alluded to the fact that the workforce met several challenges in their daily jobs and they learnt through those experiences. These study findings also supported the study by McKay et al., (2008), who found out that a variable such as job tenure paired with experience influence on performance. In this study experience diversity was among those factors with the highest influence on performance of rural roads construction projects at $86.1 \%$. These study findings are also in line with the studies by Dulaimi (2005), and Toor and Ofori (2008) that experience promotes performance of organisations.

However this study was unique in the sense that it investigated the perceptions of the workers on how being dissimilar or similar affected the performance of the rural roads construction projects unlike the earlier studies who based their study on senior management levels. The results also showed that the influence of the implementation process of project control systems on performance of rural roads was significant as well as the influence of project team experience diversity on performance of rural roads projects was also significant. This was in support of other studies such as Sosa (2008), Faraj and Sproull (2000), Gavetti et al. (2005), Huckman, Staats and Upton (2009) and Siemsen et al. (2009). However in this study the moderating role of project team experience diversity on the relationship between 
implementation process of project control systems and performance of rural roads was insignificant.

The results obtained from the in depth interviews and focused group discussions further indicated that many of the construction workers' performance was highly dependent on experience. It was clearly demonstrated that the major factor considered during recruitment was experience. Most of the workers interviewed had obtained experience from the other companies and hence the diversities of the experiences among the workers were highly correlated to performance of the rural roads construction projects. The correlation (r) between implementation process of project control systems when project team experience diversity was introduced and performance of rural roads construction projects improved to 0.828 indicating a very strong relationship.

\section{Conclusion}

In conclusion descriptive statistics showed that workers gained experience by working in various departments and this improved on their performance. It can therefore be concluded that in majority of the construction companies, diverse experience of the workers improved on their performance. The results from inferential statistics indicated that project team experience diversity does not influence on the relationship between implementation process of project control systems and performance of rural roads construction projects since the hypothesis was tested at $14.5 \%$ confidence interval which was way below the minimum threshold of $95 \%$. It was therefore concluded that there was a positive influence of project team experience diversity on performance of rural roads construction projects in Kenya. This implied that rural roads contractors should diversify their employees with different project team experience diversities in terms of the previous employment, period employed and departments worked and the impact is that it directly affects performance of projects. By so doing performance of their project would increase.

A diverse and experienced project team which interacts well with each other, is likely to foster high performance. This is concurrence with Harrison et al., (2002) who stated that team integration focusing on similarities of deep-level characteristics such as core values, beliefs, and attitudes, and maximizing individual differences of knowledge, skills, and abilities may produce successful teams and be a strong predictor of team performance. The diverse experience among the professionals should be encouraged, communicated and shared for the common purpose of achieving high performance. Interventions on project team experience diversities should target the individual relationships, the project team, the 
implementation process of project control systems, and the organization as a holistic approach for the best long-term improved performance results on rural roads construction projects.

\section{Recommendations}

It is recommended that construction companies staffing strategy should leverage on experience diversity of the workforce when making staffing decisions. When Project Managers are considering project portfolios it is important to consider their employees' huge experiences and encourage sharing among themselves. Teams should be kept together to improve on familiarity which will eventually impact on the performance of the projects. Interventions such as diversity training should target teams as opposed to individuals. These trainings should be designed to emphasize on interactions between the workers of varied experiences. Companies should perpetually examine their processes with an aim of improving on them as concerns sharing on experience diversities. It is the companies' commitments and senior management support of these policies that would see successful implementation and operationalization in their organisations.

Mentoring relationships between the old and experienced and the inexperienced young, the new and the earlier employed and this way it would likely create the conducive environment for positive performance outcomes. By so doing the feedback mechanisms should be in place to identify areas of improvements.

\section{Future studies}

The fact that this study was based on the workers and site agents only, this might make this study limited in terms of scope hence biasness. It is therefore recommended that similar study be carried out to combine other upper management staff. While the study limited itself into one sector that is rural roads construction sector the findings would not be generalized to all other sectors, however it would be interesting if this study would be mirrored in another sector setting.

\section{References:}

1. Baron, R. M., \& Kenny, D. A. (1986). The moderator-mediator variable distinction in social psychological research: Conceptual, strategic, and statistical considerations. Journal of personality and social psychology, 51(6), 1173.

2. Dulaimi, M. F. (2005). The influence of academic education and formal training on the project manager's behaviour. Journal of Construction Resource, 6(1):179-93. 
3. Faraj, S., \& Sproull, L. (2000). Coordinating expertise in software development teams. Management Science, 46(12), 1554-1569.

4. Gavetti, G., Levinthal D. A., \& Rivkin J. W., (2005). Strategy making in novel and complex worlds: the power of analogy. Strategic Management Journal. 26(8): 691-712.

5. Gilley, A., Gilley, J., McConnell, C. \& Veliquette, A., (2010). The competencies used by effective managers to build teams: an empirical study, Advances in Developing Human Resources, Vol. 12 No. 1, pp. 29-45.

6. Harrison, D. A., Price, K. H., Gavin, J., \& Florey, A., (2002). Time, teams, and task performance: Changing effects of surface and deeplevel diversity on group functioning. Academy of Management Journal 45(5): 1029-45.

7. Huckman, R. S., Staats, B. R., \& Upton, D. M., (2009). Team familiarity, role experience, and performance: Evidence from Indian software services. Management Science. 55(1): 85-100.

8. Maslach, C., Schaufeli, W.B. \& Leiter, M.P. (2001). Job burnout. Annual Review of Psychology, Vol. 52, pp. 397-422.

9. McKay, P.F., Avery, D.R. \& Morris, M.A. (2008). Mean racialethnic differences in employee sales performance: the moderating role of diversity climate. Personnel Psychology, Vol. 61, pp. 349374.

10. Porter, L., Lawler, E., \& Hackman, J., (1975). Behaviour in Organizations, McGraw-Hill, US.

11. Prahalad, C. K. \&. Bettis R. A (1986). The dominant logic: A new linkage between diversity and performance. Strategic Management Journal. 7(6): 485-501.

12. Reagans, R., Argote L., \& Brooks, D., (2005). Individual experience and experience working together: Predicting learning rates from knowing who knows what and knowing how to work together. Management Science. 51(6): 869-881.

13. Rock, D. (2006). Quiet leadership: help people think better-don't tell them what to do! New York: HarperCollins Publisher.

14. Siemsen, E., Roth, A. V., Balasubramanian, S., \& Anand, G., (2009). The influence of psychological safety and confidence in knowledge on employee knowledge sharing. Manufacturing Service Operations Management 11(3): 429-447.

15. Sosa, M. (2008). A structured approach to predicting and managing technical interactions in software development. Research in Engineering Design 19(1): 47-70. 
16. Toor, S. R., \& Ogunlana, S. O. (2008). Critical COMs of success in large-scale construction projects: Evidence from Thailand construction industry. International Journal of Project Management, 26(4), 420-430.

17. Yeager, K. L., \& Nafukho, F. M., (2012). Developing diverse teams to improve performance in the organizational setting, European Journal of Training and Development, Vol. 36 Iss 4 pp. 388 - 408. 